\title{
Relationships Between Percentage of Forest Coverage and Standardized Mortality Ratios (SMR) of Cancers in all Prefectures in Japan
}

\author{
Qing Li*, Maiko Kobayashi and Tomoyuki Kawada
}

Department of Hygiene and Public Health, Nippon Medical School, Tokyo, Japan

\begin{abstract}
Objectives: To explore whether forest coverage affects the rate of deaths due to cancers in Japan, we investigated the relationships between the percentage of forest coverage and standardized mortality ratios due to cancers in all prefectures in Japan.

Methods: Data on the percentage of forest coverage in all prefectures in Japan were collected from the database of the Forestry Agency of Japan. Data on standardized mortality ratios (SMR) due to lung, stomach, kidney, and colon cancers in males and females, breast and uterine cancers in females, and prostate cancer in males, and data of smoking status of males and females in all prefectures in Japan were collected from the database of the Ministry of Health, Labour, and Welfare of Japan. Human development index (HDI) was used as a parameter of the socioeconomic status of each prefecture. The correlation and partial correlation coefficients between the percentage of forest coverage and SMR of cancers, after controlling for the effects of smoking and the socioeconomic status, were calculated.

Results: People living in areas with lower forest coverage had significantly higher SMR of cancers compared with the people living in areas with higher forest coverage. There were significant inverse correlations between the percentage of forest coverage and the SMR of lung, breast, and uterine cancers in females, and the SMR of prostate, kidney, and colon cancers in males in all prefectures in Japan, even after the effects of smoking and socioeconomic status were factored in.

Conclusions: These findings indicate that increased forest coverage may partially contribute to a decrease in mortality due to cancers in Japan.
\end{abstract}

Keywords: Breast cancer, colon cancer, HDI, kidney cancer, percentage of forest coverage, prostate cancer, SMR, uterine cancer.

\section{INTRODUCTION}

A forest bathing trip, called "Shinrinyoku" in Japanese, involves a visit to a forest area for the purpose of relaxation and recreation by breathing in volatile substances, called phytoncides, released from the trees (Li et al., 2007; 2008a; 2008b). These trips were first proposed in the 1980s and have become a recognized relaxation activity in Japan (Ohtsuka et al., 1998; Yamaguchi et al., 2006; Li et al., 2007; 2008a; 2008b; Morita et al., 2007; Park et al., 2007). Since forests occupy 67\% of the land in Japan (Forestry Agency of Japan, 2002), forest bathing is easily accessible. According to a public opinion poll conducted in Japan in $2003,25.6 \%$ of respondents had participated in a forest bathing trip, indicating its popularity in Japan (Morita et al., 2007). Moreover, forest bathing is possible in similar environments throughout the world. We reported previously that phytoncides such as alpha-pinene, 1,8-cineole, and dlimonene extracted from trees significantly enhanced human natural killer (NK) activity and intracellular levels of perforin, granulysin (GRN), and granzyme A (GrA) in human NK cells in vitro (Li et al., 2006). (Komori et al., 1995) also reported that citrus fragrance found in forests affects the human endocrine and immune systems as analyzed by the measurement of urinary cortisol and dopamine levels, NK

*Address correspondence to this author at the Department of Hygiene and Public Health, Nippon Medical School, 1-1-5 Sendagi, Bunkyo-ku, Tokyo 113-8602, Japan; Tel: +81-3-3822-2131; Fax: +81-3-5685-3065;

E-mail: qing-li@nms.ac.jp activity, and CD4/8 ratios. These findings suggest that forest bathing may have beneficial effects on human immune function. Thus, we previously investigated the effect of forest bathing trips on human NK activity, and found increased human NK activity, NK cell numbers, and intracellular levels of perforin, GRN, and GrA/B in peripheral blood lymphocytes (Li et al., 2007). Moreover, we also found that the increased NK activity, number of NK cells, and intracellular anti-cancer proteins induced by a forest bathing trip lasted more than 7 days, even 30 days, after the trip both in males (Li et al., 2008a) and females (Li et al., 2008b). Cytolytic molecules such as perforin, GRN, and GrA/B contribute to anti-tumor activity (Krensky and Clayberger, 2005; Huang et al., 2007). These findings suggest that forests may have anticancer effects by enhancing human NK activity and partially contribute to decreased rates of death due to cancers. These findings also encouraged us to propose a hypothesis that people living in areas with higher forest coverage may show lower mortality due to cancers; thus, we investigated the relationship between the percentage of forest coverage and standardized mortality ratios (SMR) due to cancers in all prefectures in Japan to verify this hypothesis in the present study. SMR measures the level of excess or deficit in mortality in a study population compared with the expected level based on the mortality of a standard population. SMR is computed as the ratio of the observed deaths to the expected deaths in the study population. The expected deaths are obtained by multiplying the age-specific mortality rate of a chosen standard population by the age-specific population 
Table 1a. Rate of Forest Coverage, SMR of Cancers, and Smoking Rate in Females in Each Prefecture of Japan

\begin{tabular}{|c|c|c|c|c|c|c|c|c|c|}
\hline Prefecture & $\begin{array}{c}\text { Forest cov- } \\
\text { erage }(\%)\end{array}$ & $\begin{array}{c}\text { Lung } \\
\text { Cancer }\end{array}$ & $\begin{array}{l}\text { Breast } \\
\text { Cancer }\end{array}$ & $\begin{array}{l}\text { Uterine } \\
\text { Cancer }\end{array}$ & $\begin{array}{c}\text { Stomach } \\
\text { Cancer }\end{array}$ & $\begin{array}{c}\text { Colon } \\
\text { Cancer }\end{array}$ & $\begin{array}{l}\text { Kidney } \\
\text { Cancer }\end{array}$ & $\begin{array}{l}\text { Smoking } \\
\text { rate }(\%)\end{array}$ & HDI* \\
\hline Hokkaido & 71 & 109.3 & 105.8 & 97.3 & 89.9 & 106.8 & 116.5 & 12.1 & 0.93 \\
\hline Aomori & 66 & 93.6 & 100.8 & 89.8 & 101.1 & 112.1 & 139.4 & 5.4 & 0.913 \\
\hline Iwate & 77 & 83.7 & 88.8 & 88.3 & 83.9 & 108.7 & 81 & 3.7 & 0.925 \\
\hline Miyagi & 57 & 95.3 & 98.4 & 86.4 & 92.1 & 107.7 & 104.7 & 5.1 & 0.931 \\
\hline Akita & 72 & 87.9 & 80.7 & 77.3 & 118.3 & 113.2 & 114.2 & 3.3 & 0.92 \\
\hline Yamagata & 72 & 89.3 & 79.2 & 82.2 & 122.5 & 108.8 & 98.5 & 4.5 & 0.927 \\
\hline Fukushima & 71 & 91 & 79.8 & 86.2 & 100.7 & 99.9 & 101.8 & 5.5 & 0.928 \\
\hline Ibaraki & 31 & 82.9 & 95 & 105.7 & 108.9 & 96.3 & 124.7 & 5.3 & 0.931 \\
\hline Tochigi & 55 & 89.6 & 96.5 & 99.7 & 115.4 & 92.9 & 85.9 & 6.4 & 0.935 \\
\hline Gunma & 67 & 80.3 & 92.5 & 84.5 & 102 & 89.2 & 88.9 & 7.1 & 0.935 \\
\hline Saitama & 32 & 96.7 & 104.2 & 101 & 108.4 & 101.8 & 98.6 & 7.7 & 0.919 \\
\hline Chiba & 32 & 95.8 & 107.1 & 100.7 & 102.9 & 101.7 & 88.9 & 6.7 & 0.926 \\
\hline Tokyo & 36 & 110 & 132 & 114 & 102 & 111.7 & 111.8 & 9.6 & 0.972 \\
\hline Kanagawa & 39 & 105.4 & 117.4 & 97.5 & 101.4 & 106 & 87.8 & 8.8 & 0.935 \\
\hline Niigata & 69 & 86.2 & 86.9 & 65.4 & 112.9 & 105.8 & 68.1 & 4 & 0.935 \\
\hline Toyama & 67 & 87.3 & 90.9 & 71.3 & 125.5 & 102.2 & 114.2 & 3.6 & 0.943 \\
\hline Ishikawa & 69 & 97 & 96 & 97.7 & 106 & 94.4 & 67.6 & 6.9 & 0.94 \\
\hline Fukui & 75 & 83.6 & 91 & 82.2 & 100.9 & 84.8 & 110.3 & 3 & 0.944 \\
\hline Yamanashi & 78 & 77.3 & 100.2 & 88.3 & 88.9 & 85.7 & 116.5 & 5.9 & 0.937 \\
\hline Nagano & 78 & 72.9 & 88.7 & 81.3 & 94.3 & 98.8 & 61.6 & 3.1 & 0.941 \\
\hline Gifu & 82 & 87.2 & 93.7 & 109.7 & 110.9 & 108.8 & 147.2 & 4.7 & 0.931 \\
\hline Shizuoka & 64 & 83.2 & 91.9 & 93.2 & 89 & 91 & 108.3 & 5.2 & 0.944 \\
\hline Aichi & 43 & 105.8 & 101.4 & 102.5 & 109.3 & 108.8 & 95.6 & 7.3 & 0.949 \\
\hline Mie & 65 & 90 & 95.1 & 94.1 & 99.6 & 88.3 & 88.1 & 3.5 & 0.935 \\
\hline Shiga & 51 & 97.6 & 88.7 & 85.4 & 110.1 & 95.2 & 102.9 & 4.5 & 0.946 \\
\hline Kyoto & 75 & 108.9 & 99.4 & 91 & 105.4 & 102.5 & 79.3 & 7.3 & 0.939 \\
\hline Osaka & 31 & 127.1 & 110 & 115 & 108 & 105.5 & 113.1 & 11 & 0.944 \\
\hline Hyogo & 67 & 110.5 & 101.3 & 112.4 & 103.6 & 99.8 & 110.2 & 4.2 & 0.933 \\
\hline Nara & 77 & 107 & 92.1 & 109.3 & 117 & 93 & 84.2 & 5.3 & 0.92 \\
\hline Wakayama & 77 & 97.7 & 81.3 & 102.4 & 109.3 & 90.8 & 89.6 & 5.7 & 0.921 \\
\hline Tottori & 74 & 94.3 & 88.4 & 105.8 & 110 & 92.3 & 111.2 & 2.4 & 0.931 \\
\hline Shimane & 79 & 84.6 & 77.6 & 84.9 & 99.7 & 95.4 & 61.8 & 2.5 & 0.928 \\
\hline Okayama & 68 & 90.9 & 74.2 & 84.6 & 89 & 90.2 & 118.6 & 3.3 & 0.936 \\
\hline Hiroshima & 72 & 97.1 & 94 & 107.7 & 92.6 & 94.1 & 122.2 & 2.9 & 0.94 \\
\hline Yamaguchi & 71 & 105.9 & 93 & 94.4 & 92.8 & 89.6 & 112.3 & 3.5 & 0.931 \\
\hline Tokushima & 75 & 97.7 & 86.5 & 113.5 & 93.5 & 84.7 & 83.1 & 5.1 & 0.928 \\
\hline Kagawa & 47 & 90.2 & 78.4 & 101.9 & 103.1 & 84.4 & 125.2 & 4 & 0.936 \\
\hline Ehime & 71 & 92 & 88.3 & 101.5 & 98.4 & 79.9 & 68.6 & 2.7 & 0.927 \\
\hline Kochi & 84 & 88 & 79.5 & 106.6 & 91.1 & 84.5 & 52.2 & 3.7 & 0.921 \\
\hline Fukuoka & 45 & 120 & 104 & 109.4 & 98.5 & 104 & 104.9 & 5.9 & 0.928 \\
\hline Saga & 45 & 100.9 & 87 & 111.8 & 98.1 & 101.5 & 109.6 & 3.1 & 0.924 \\
\hline Nagasaki & 60 & 107.3 & 90.1 & 100.1 & 90.6 & 101.5 & 101 & 4.1 & 0.918 \\
\hline Kumamoto & 63 & 98.3 & 85.9 & 96.1 & 71.7 & 83.1 & 138.7 & 4.5 & 0.928 \\
\hline Oita & 72 & 94.3 & 82.2 & 106.4 & 88.9 & 86.7 & 58.2 & 4.3 & 0.935 \\
\hline Miyazaki & 76 & 87.3 & 82.2 & 108.4 & 78.3 & 82.2 & 105.4 & 3.8 & 0.92 \\
\hline Kagoshima & 64 & 96.9 & 75.5 & 107.3 & 68.3 & 87 & 49.7 & 2.1 & 0.919 \\
\hline Okinawa & 46 & 125.1 & 80.9 & 122.6 & 47.4 & 83.6 & 34.6 & 4.6 & 0.914 \\
\hline
\end{tabular}

*: HDI: Human Development Index. 
Table 1b. Rate of Forest Coverage, SMR of Cancers, and Smoking Rate in Males in Each Prefecture of Japan

\begin{tabular}{|c|c|c|c|c|c|c|c|c|}
\hline Prefectures & $\begin{array}{c}\text { Forest cov- } \\
\text { erage }(\%)\end{array}$ & Lung cancer & $\begin{array}{l}\text { Stomach } \\
\text { cancer }\end{array}$ & Colon cancer & $\begin{array}{c}\text { Prostate } \\
\text { cancer }\end{array}$ & $\begin{array}{l}\text { Kidney } \\
\text { cancer }\end{array}$ & $\begin{array}{c}\text { Smoking rate } \\
(\%)\end{array}$ & HDI* \\
\hline Hokkaido & 71 & 109.2 & 93.6 & 107.8 & 91.5 & 101.8 & 36.2 & 0.93 \\
\hline Aomori & 66 & 110.7 & 111.1 & 116.6 & 119.1 & 149.4 & 47.7 & 0.913 \\
\hline Iwate & 77 & 96.7 & 86.4 & 104 & 118.7 & 109.4 & 31.8 & 0.925 \\
\hline Miyagi & 57 & 103 & 97.2 & 100.7 & 107.8 & 87.5 & 37.7 & 0.931 \\
\hline Akita & 72 & 97.2 & 128.8 & 108.3 & 95.5 & 94.2 & 38.7 & 0.92 \\
\hline Yamagata & 72 & 99.4 & 114.3 & 103.3 & 102 & 112.8 & 35.3 & 0.927 \\
\hline Fukusihma & 71 & 95.8 & 107.9 & 99.7 & 109.9 & 94.8 & 33.6 & 0.928 \\
\hline Ibaraki & 31 & 93.3 & 111 & 98.4 & 108.3 & 111.3 & 36.4 & 0.931 \\
\hline Tochigi & 55 & 94.1 & 117.7 & 98.4 & 101.7 & 96.8 & 39.3 & 0.935 \\
\hline Gunma & 67 & 89.2 & 99.5 & 89.8 & 99.1 & 113.1 & 35.6 & 0.935 \\
\hline Saitama & 32 & 96.5 & 106.7 & 102.5 & 104 & 109.3 & 31 & 0.919 \\
\hline Chiba & 32 & 90.2 & 107.9 & 103.3 & 109.3 & 98.6 & 31.9 & 0.926 \\
\hline Tokyo & 36 & 96.4 & 101.7 & 112.9 & 109.5 & 121.8 & 31.1 & 0.972 \\
\hline Kanagawa & 39 & 92.5 & 101.6 & 108.5 & 112.3 & 105.1 & 33.4 & 0.935 \\
\hline Niigata & 69 & 102.2 & 115.8 & 103.4 & 86.7 & 106.4 & 33.2 & 0.935 \\
\hline Toyama & 67 & 96.2 & 111.8 & 96.1 & 84.5 & 114.7 & 29 & 0.943 \\
\hline Ishikawa & 69 & 103.6 & 106.4 & 97.9 & 87.9 & 92.7 & 47.5 & 0.94 \\
\hline Fukui & 75 & 100.6 & 89.6 & 86 & 92.5 & 114.1 & 32.8 & 0.944 \\
\hline Yamanashi & 78 & 86.3 & 91.3 & 81.4 & 102.1 & 39 & 44.7 & 0.937 \\
\hline Nagano & 78 & 72.4 & 92.7 & 90.2 & 109.1 & 84 & 29.4 & 0.941 \\
\hline Gifu & 82 & 91.8 & 100.1 & 93.7 & 101.5 & 71.4 & 34.8 & 0.931 \\
\hline Shizuoka & 64 & 86.1 & 89.7 & 92.7 & 113.1 & 92.1 & 29.3 & 0.944 \\
\hline Aichi & 43 & 104.5 & 100.9 & 99.7 & 96.5 & 89.7 & 29.1 & 0.949 \\
\hline Mie & 65 & 101.6 & 95.3 & 90.4 & 67.4 & 118.5 & 29.9 & 0.935 \\
\hline Shiga & 51 & 113.8 & 99.3 & 89.7 & 106.6 & 113.5 & 32.6 & 0.946 \\
\hline Kyoto & 75 & 111.9 & 100.7 & 103.2 & 95.1 & 94.9 & 33.3 & 0.939 \\
\hline Osaka & 31 & 117.3 & 109.5 & 103.4 & 90.9 & 106.3 & 42.6 & 0.944 \\
\hline Hyogo & 67 & 111.3 & 104 & 103.8 & 89.6 & 107.9 & 31.4 & 0.933 \\
\hline Nara & 77 & 106.3 & 107.5 & 91.6 & 93.9 & 86 & 31.7 & 0.92 \\
\hline Wakayama & 77 & 115.7 & 104 & 92.6 & 83.2 & 90.2 & 34.6 & 0.921 \\
\hline Tottori & 74 & 99.4 & 101.1 & 106.8 & 83.2 & 61 & 30 & 0.931 \\
\hline Shimane & 79 & 91.2 & 94.3 & 98.8 & 92.3 & 57.2 & 25 & 0.928 \\
\hline Okayama & 68 & 96.7 & 88.5 & 81.2 & 94.6 & 72.7 & 30.3 & 0.936 \\
\hline Hiroshima & 72 & 97.3 & 93.3 & 95.1 & 91.5 & 91.8 & 22.7 & 0.94 \\
\hline Yamaguchi & 71 & 104.5 & 98.2 & 94.5 & 67.2 & 96.6 & 25.7 & 0.931 \\
\hline Tokushima & 75 & 99.2 & 94.5 & 84.7 & 69.8 & 88.5 & 30.1 & 0.924 \\
\hline Kagawa & 47 & 100.4 & 102.3 & 78.5 & 88.7 & 93.3 & 29.7 & 0.936 \\
\hline Ehime & 71 & 100 & 96.7 & 84.2 & 69.6 & 77.1 & 33 & 0.927 \\
\hline Kochi & 84 & 86.2 & 90.3 & 97.5 & 99.8 & 86.1 & 28.6 & 0.921 \\
\hline Fukuoka & 45 & 108 & 100.3 & 101.5 & 98.9 & 106.6 & 31.8 & 0.928 \\
\hline Saga & 45 & 104.8 & 101.1 & 106.6 & 148.5 & 80.6 & 34.1 & 0.924 \\
\hline Nagasaki & 60 & 112.5 & 89.1 & 106.3 & 113.8 & 106.4 & 35.2 & 0.918 \\
\hline Kumamoto & 63 & 90.2 & 70 & 83.8 & 110.1 & 91.5 & 32.4 & 0.928 \\
\hline Oita & 72 & 97.5 & 82 & 87.5 & 101 & 74.4 & 37.2 & 0.935 \\
\hline Miyazaki & 76 & 92.3 & 84.5 & 89.6 & 104.6 & 86.3 & 26.7 & 0.92 \\
\hline Kagoshima & 64 & 99 & 71.3 & 89 & 113.8 & 80.8 & 27 & 0.919 \\
\hline Okinawa & 46 & 123.1 & 56.9 & 96.2 & 104.9 & 80.5 & 25.7 & 0.914 \\
\hline
\end{tabular}

*: HDI: Human Development Index. 
size of the study population and then adding terms to get the total expected number of deaths (Lai et al., 2000).

\section{MATERIALS AND METHODS}

As shown in Tables $\mathbf{1 a}$ and $\mathbf{1 b}$, data of the percentage of forest coverage in all prefectures in Japan in 2002 were collected from the database of the Forestry Agency of Japan (Forestry Agency of Japan, 2002). Data of standardized mortality ratios (SMR) of lung, stomach, kidney, and colon cancers in males and females, and SMR of breast and uterine cancers in females and prostate cancer in males in all prefectures in Japan in 1998 and 1999 were collected from the database of the Ministry of Health, Labour, and Welfare of Japan (Ministry of Health, Labour and Welfare of Japan, 2001). We used the mean SMR of cancers in 1998 and 1999 for all cancers in the present study. Since smoking status influences the SMR of cancers (Mellemgaard et al., 1994; Mizoue et al., 2000; Minami and Tateno, 2003; Bjartveit and Tverdal, 2005; Toh et al., 2007; Ambrosone et al., 2008; Gong et al., 2008), especially for lung cancer (Minami and Tateno, 2003; Bjartveit and Tverdal, 2005; Toh et al., 2007), data on the smoking status in males and females in 2003 were also collected from the database of the Ministry of Health, Labour, and Welfare of Japan (Ministry of Health, Labour and Welfare of Japan, 2003). Since socioeconomic status is also a risk factor for cancers (Datta et al., 2006;
Fagundes et al., 2006; Goy et al., 2008; Menvielle et al., 2008) we have to take it into account. The human development index (HDI) is a composite score used by the United Nations Development Programme to rank countries in terms of their human socioeconomic development status (Landry and Raman, 2007), which is a composite index of life expectancy, literacy, and per capita gross domestic product that measures the socioeconomic status of a country (Lee et al., 1997). HDI has been used to estimate infant and maternal mortality rates around the world and assessed how well the HDI and its individual components predicted infant and maternal mortality rates for individual countries (Lee et al., 1997). In the present study, we used HDI as a parameter of socioeconomic status in each prefecture (Umemura, 2001). We first calculated the correlation coefficients between the percentage of forest coverage and SMR of cancers. Then, if the correlations were significant, the partial correlation coefficients between the percentage of forest coverage and SMR of cancers after factoring in the effects of smoking and socioeconomic status were also calculated.

\section{Statistical Analysis}

The correlation and partial correlation coefficients were calculated and an unpaired t-test was performed using the SPSS 14.0 software package for Windows. The significance level for $\mathrm{p}$ values was set at $<0.05$.

Table 2a. Correlation and Partial Correlation Coefficients Between the Rate of Forest Coverage and SMR of Cancers in all Prefectures of Japan Corrected by Smoking Rate and HDI in Females

\begin{tabular}{|c|c|c|c|c|}
\hline Female & Correlation coefficients & $\begin{array}{c}\text { Partial correlation coeffi- } \\
\text { cients1\# }\end{array}$ & $\begin{array}{c}\text { Partial correlation coeffi- } \\
\text { cients2\# }\end{array}$ & $\begin{array}{c}\text { Partial correlation coeffi- } \\
\text { cients3\# }\end{array}$ \\
\hline \hline Lung Cancer & $-0.455^{* *}$ & $-0.304^{*}$ & $-0.468^{* *}$ & $-0.325^{*}$ \\
\hline Breast Cancer & $-0.530^{* *}$ & $-0.312^{*}$ & $-0.501^{* *}$ & $-0.308^{*}$ \\
\hline Uterine Cancer & $-0.328^{*}$ & -0.269 & $-0.377^{*}$ & $-0.293^{*}$ \\
\hline Stomach cancer & -0.050 & 0.027 & 0.008 & 0.048 \\
\hline Colon Cancer & -0.271 & -0.101 & -0.247 & -0.099 \\
\hline Kidney cancer & -0.136 & -0.078 & -0.102 & -0.068 \\
\hline
\end{tabular}

$*: \mathrm{p}<0.05, * *: \mathrm{p}<0.001$.

1\#: corrected by smoking rate, $2 \#$ corrected by HDI, $3 \#$ : corrected by both smoking rate and HDI.

Table 2b. Correlation and Partial Correlation Coefficients Between the Rate of Forest Coverage and SMR of Cancers in all Prefectures of Japan Corrected by Smoking Rate and HDI in Males

\begin{tabular}{|c|c|c|c|c|}
\hline Male & Correlation coefficients & $\begin{array}{c}\text { Partial correlation coeffi- } \\
\text { cients1\# }\end{array}$ & $\begin{array}{c}\text { Partial correlation coeffi- } \\
\text { cients2\# }\end{array}$ & $\begin{array}{c}\text { Partial correlation coeffi- } \\
\text { cients3\# }\end{array}$ \\
\hline \hline Lung Cancer & -0.214 & -0.207 & -0.258 & -0.251 \\
\hline Stomach cancer & -0.146 & -0.131 & -0.120 & -0.100 \\
\hline Prostate cancer & $-0.315^{*}$ & $-0.309 *$ & $-0.351^{*}$ & $-0.345^{*}$ \\
\hline Kidney cancer & $-0.348^{*}$ & $-0.342^{*}$ & $-0.334^{*}$ & $-0.327^{*}$ \\
\hline Colon Cancer & $-0.299^{*}$ & $-0.293^{*}$ & $-0.312^{*}$ & $-0.311^{*}$ \\
\hline
\end{tabular}

$*: \mathrm{p}<0.05$.

$1 \#$ : corrected by smoking rate, $2 \#$ corrected by HDI, $3 \#$ : corrected by both smoking rate and HDI. 


\section{RESULTS}

\section{Correlation Between the Percentage of Forest Coverage and SMR of Cancers}

As shown in Tables $\mathbf{2 a}$ and $\mathbf{b}$, there were significant inverse correlations between the percentage of forest coverage and SMR of lung $(\mathrm{r}=-0.455, \mathrm{p}<0.001)$, breast $(\mathrm{r}=-0.530$, $\mathrm{p}<0.0001)$, and uterine cancers $(\mathrm{r}=-0.328, \mathrm{p}<0.05)$ in females, and SMR of prostate $(\mathrm{r}=-0.315, \mathrm{p}<0.05)$, kidney $(\mathrm{r}=-$ $0.348, \mathrm{p}<0.05)$, and colon cancers $(\mathrm{r}=-0.299, \mathrm{p}<0.05)$ in males. On the other hand, there was no significant correlation between the percentage of forest coverage and SMR of stomach, kidney, and colon cancers in females and lung and stomach cancers in males.

As shown in Fig. (1), we further grouped the SMR of breast cancer in females and the SMR of prostate cancer in males by forest coverage in all prefectures in Japan and found that people living in areas with lower forest coverage had significantly higher SMR of breast and prostate cancers compared with the people living in areas with higher forest coverage.

\section{Partial Correlation Coefficients Between the Percentage of Forest Coverage and SMR of Cancers after the Effects of Smoking and Socioeconomic Status were Factored in}

Since smoking status influences the SMR of cancers (Mellemgaard et al., 1994; Mizoue et al., 2000; Minami and Tateno, 2003; Bjartveit and Tverdal, 2005; Toh et al., 2007; Ambrosone et al., 2008; Gong et al., 2008), and there was a significant positive correlation between the SMR of lung cancer and smoking rates in each prefecture in females, we further calculated the partial correlation coefficients between the percentage of forest coverage and SMR of cancers after the effect of smoking was factored in. As shown in Tables 2a and $\mathbf{b}$, there were still significant inverse relationships between the percentage of forest coverage and SMR of lung

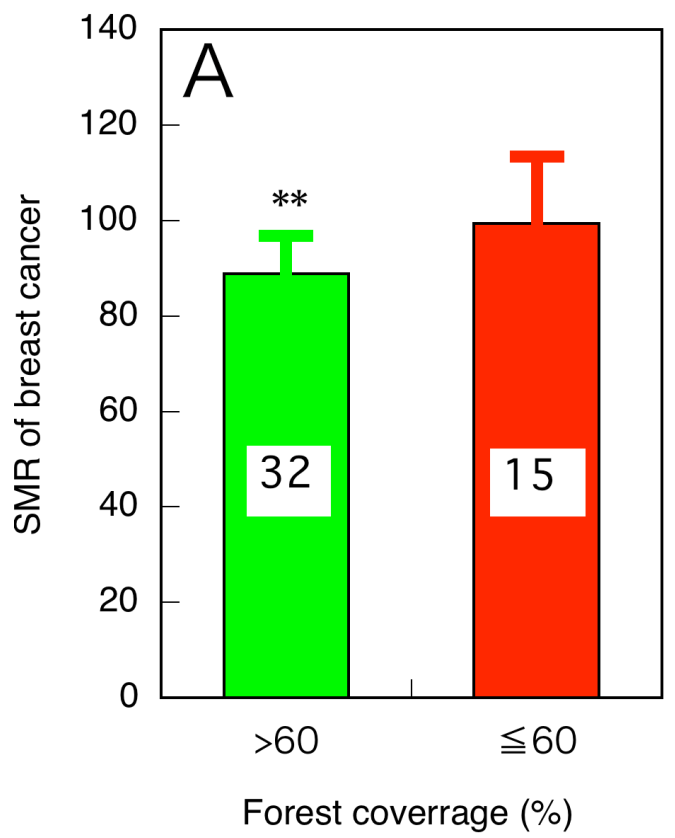

$(\mathrm{r}=-0.304, \mathrm{p}<0.05)$ and breast $(\mathrm{r}=-0.312, \mathrm{p}<0.05)$ cancers in females, and SMR of prostate $(r=-0.309, \mathrm{p}<0.05)$, kidney $(\mathrm{r}=-0.342, \mathrm{p}<0.05)$, and colon cancers $(\mathrm{r}=-0.293, \mathrm{p}=0.05)$ in males after the effect of smoking was factored in. Socioeconomic status also affects the mortality rate due to cancers (Datta et al., 2006; Fagundes et al., 2006; Goy et al., 2008; Menvielle et al., 2008), and HDI has been used to evaluate the socioeconomic status of countries (Landry and Raman, 2007). We further calculated the partial correlation coefficients between the percentage of forest coverage and SMR of cancers after the effect of socioeconomic status (HDI) was factored in. As shown in Tables 2a and $\mathbf{b}$, there were still significant inverse relationships between the percentage of forest coverage and SMR of lung $(r=-0.468, p<0.001)$, breast $(\mathrm{r}=-0.501, \mathrm{p}<0.001)$, and uterine $(\mathrm{r}=-0.377, \mathrm{p}<0.05)$ cancers in females, and SMR of prostate $(\mathrm{r}=-0.351, \mathrm{p}<0.05)$, kidney $(\mathrm{r}=-0.334, \mathrm{p}<0.05)$, and colon cancers $(\mathrm{r}=-0.312, \mathrm{p}<0.05)$ in males after the effect of socioeconomic status was factored in. Moreover, there were still significant inverse relationships between the percentage of forest coverage and SMR of lung $(\mathrm{r}=-0.325, \mathrm{p}<0.05)$, breast $(\mathrm{r}=-0.308, \mathrm{p}<0.05)$, and uterine $(r=-0.293, p=0.05)$ cancers in females, and SMR of prostate $(\mathrm{r}=-0.345, \mathrm{p}<0.05)$, kidney $(\mathrm{r}=-0.327, \mathrm{p}<0.05)$, and colon cancers $(r=-0.311, p<0.05)$ in males after the effects of smoking and socioeconomic status were factored in, suggesting that forest coverage indeed affects the SMR of cancers.

\section{DISCUSSION}

We found previously that a forest bathing trip increased human NK activity, number of NK cells, and intracellular levels of perforin, GRN, and GrA/B in PBL (Li et al., 2007). Moreover, we also found that the increased NK activity, number of NK cells, and intracellular anti-cancer proteins induced by a forest bathing trip lasted more than 7 days, even 30 days, after the trip (Li et al., 2008a; 2008b). On the other hand, a city tourist visit to an area without forests did

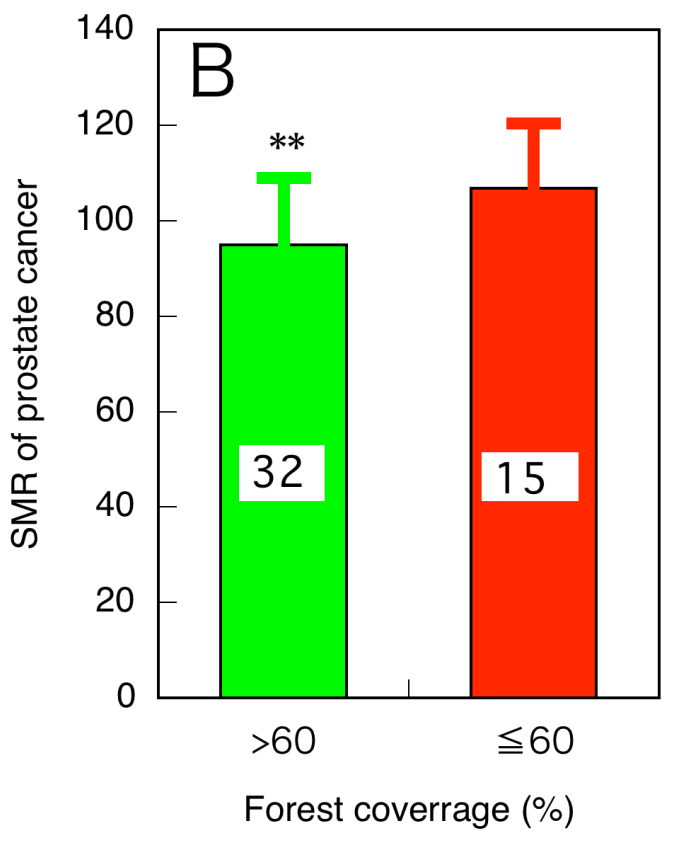

Fig. (1). The SMR of breast cancer in females (A) and the SMR of prostate cancer in males (B) grouped by percentage of forest coverage of each prefecture in Japan. Data are presented as the mean+SD, the numbers in columns indicate the number of prefectures. $* *: p<0.001$, significantly different from the percentage of forest coverage of $\leqq 60 \%$, respectively, by unpaired t-test. 
not affect human NK activity (Li et al., 2008a). Increased NK activity and intracellular anti-cancer proteins contribute to anti-tumor activity (Krensky and Clayberger, 2005; Huang et al., 2007). This suggests that forests may have a preventive effect on cancer development and contribute to a decreased rate of death due to cancers. These findings also encouraged us to propose a hypothesis that people living in areas with higher forest coverage may show lower mortality due to cancers. The present study indicated that there is a significant inverse correlation between forest coverage and SMR of cancers, and that people living in areas with higher forest coverage show a significantly lower SMR of cancers compared with people living in areas with lower forest coverage. This may be important in health promotion and preventive medicine.

Cigarette smoking is an important risk factor for lung (Minami and Tateno, 2003; Bjartveit and Tverdal, 2005; Toh et al., 2007) and stomach cancers (Mizoue et al., 2000; Minami and Tateno, 2003) and smoking increases the risk of breast cancer among women (Ambrosone et al., 2008). Gong et al. (2008) also reported that smoking at the time of diagnosis, independent of key clinical prognostic factors, is associated with an increased risk of prostate cancer death. Both cigarette smoking and socioeconomic status are risk factors for kidney cancer (Mellemgaard et al., 1994). Socioeconomic status is a risk factor for uterine cancer by affecting the utilization of efficacious screening tools in the early detection of the disease (Datta et al., 2006). Therefore, the effects of smoking and socioeconomic status have also to be factored in. Thus, we further analyzed the partial correlation between forest coverage and SMR of cancers and found significant inverse correlations between forest coverage and SMR of cancers even after the effects of smoking and the socioeconomic status was factored in, suggesting that forests indeed decrease the mortality due to cancers in Japan.

The percentage of forest coverage correlated significantly with the SMR of lung cancer in females, but not in males, whereas, the forest coverage correlated significantly with the SMR of kidney and colon cancers in males, but not in females. Although we can not exactly explain the difference between genders, the higher average smoking rate in males $(33.1 \%)$ than in females $(6.4 \%)$ (Ministry of Health, Labour and Welfare of Japan, 2003) may have a larger influence on the SMR of lung cancer than the effect of forest coverage, and the effect of forest coverage on lung cancer was less significant than the effect of smoking. It is well known that smoking increases the risk of lung cancer (Minami and Tateno, 2003; Bjartveit and Tverdal, 2005; Toh et al., 2007). However, there was no association between cigarette smoking and the risk of colon cancer (Minami and Tateno, 2003). It is still difficult to explain the difference in the effect of forest coverage on kidney and colon cancers between genders. The percentage of forest coverage correlated significantly with the SMR of breast and uterine cancers in females, and the SMR of prostate cancer in males. Although we can not exactly explain the mechanism, sex hormones may partially contribute to this difference.

The percentage of forest coverage had no effect on the SMR of stomach cancer in either males or females. It is well known that certain bacteria increase the risk of stomach cancer (IARC, 1994). In areas where gastric cancer is highly prevalent, such as Japan, Korea, and China, the great majority of gastric cancers are Helicobacter pylori-related. In Japan, the cumulative gastric cancer incidence rate of 0 84-year-olds was estimated to be $21.2 \%$ for infected males and $8.0 \%$ for infected females, under the conditions that half of the population is infected and infected people have a fivetimes higher risk of gastric cancer than uninfected people (Hamajima et al., 2004). These findings suggest that $H$. pylori infection (IARC, 1994) and dietary habits (Tsugane, 2004) have more effect on stomach cancer than the effect of forest coverage, and the effect of forest coverage on stomach cancer was less significant than the effect of other factors such as $H$. pylori infection and dietary habits.

There are several limitations in the present study. One is the use of information on smoking in 2003, whereas the data of SMR of cancers refer to 1998-99. Unfortunately, we could not obtain the data of SMR of cancers and the smoking rates for the same year; therefore, the use of 2003-related information on smoking as an adjusting factor for the correlations currently assessed should be an approximate indication of the smoking rate. However, the smoking rate should not change much during 1998-2003 in Japan. Many factors could influence SMR of cancers, and we only calculated the confounding effects of smoking and socioeconomic status in the present study. Other confounding factors should also be considered; therefore, further studies are necessary to assess more specific information.

In summary, the present findings suggest that forests may partially contribute to decreased SMR of some cancers in Japan.

\section{ACKNOWLEDGEMENTS}

The authors are grateful to the staff at the Department of Hygiene and Public Health, Nippon Medical School for their helpful advice.

\section{REFERENCES}

Ambrosone, C.B., Kropp, S., Yang, J., Yao, S., Shields, P.G., \& ChangClaude, J. (2008). Cigarette smoking, N-acetyltransferase 2 genotypes, and breast cancer risk: pooled analysis and meta-analysis. Cancer Epidemiology, Biomarkers \& Prevention. 17, 15-26.

Bjartveit, K., \& Tverdal, A. (2005). Health consequences of smoking 1-4 cigarettes per day. Tobacco Control 14, 315-20.

Datta, G. D., Colditz, G.A., Kawachi, I., Subramanian, S.V., Palmer, J.R., \& Rosenberg, L. (2006). Individual-, neighborhood-, and state-level socioeconomic predictors of cervical carcinoma screening among U.S. black women: a multilevel analysis. Cancer 106, 664-9.

Fagundes, E.M., Rocha, V., Glória, A.B., et al. (2006). De novo acute myeloid leukemia in adults younger than 60 years of age: socioeconomic aspects and treatment results in a Brazilian university center. Leukemia \& Lymphoma 47, 1557-64.

Forestry Agency of Japan (2002). http://www.rinya.maff.go.jp/ toukei/genkyou/shinrin-jinkou.htm.

Gong, Z., Agalliu, I., Lin, D.W., Stanford, J.L., \& Kristal, A.R. (2008). Cigarette smoking and prostate cancer-specific mortality following diagnosis in middle-aged men. Cancer Causes \& Control 19(1), 25-31.

Goy, J., Rosenberg, M.W., \& King, W.D. (2008). Health risk behaviors: examining social inequalities in bladder and colorectal cancers. Annals of Epidemiology 18, 156-62.

Hamajima, N., Goto, Y., Nishio, K. et al. (2004). Helicobacter pylori eradication as a preventive tool against gastric cancer. Asian $\mathrm{Pa}$ cific Journal of Cancer Prevention 5, 246-52.

Huang, L.P., Lyu, S.C., Clayberger, C., \& Krensky, A.M. (2007). Granulysin-mediated tumor rejection in transgenic mice. Journal of Immunology 178, 77-84. 
IARC. (1994). Infection with Helicobacter pylori in IARC (Eds.), IARC Monographs on the Evaluation of the Carcinogenic Risks to Humans, Vol. 61. Schistosomes, liver flukes, and Helicobacter pylori. : International Agency for Research on Cancer p 177-241.

Komori, T., Fujiwara, R., Tanida, M., Nomura, J., \& Yokoyama, M.M. (1995). Effects of citrus fragrance on immune function and depressive states. Neuroimmunomodulation 2, 174-180.

Krensky, A.M., \& Clayberger, C. (2005). Granulysin: a novel host defense molecule. American Journal of Transplantation 5, 1789-92.

Lai, D., Guo, F., \& Hardy, R.J. (2000). Standardized mortality ratio and life expectancy: a comparative study of Chinese mortality. International Journal of Epidemiology 29, 852-5.

Landry, M.D., \& Raman, S. (2007). Millennium Development Goals (MDGs): A Global Policy Paradox. World Health \& Population 9(3), 5-8.

Lee, K.S., Park, S.C., Khoshnood, B., Hsieh, H.L., \& Mittendorf, R. (1997). Human development index as a predictor of infant and maternal mortality rates. The Journal of Pediatrics 131, 430-3.

Li, Q., Nakadai, A., Matsushima, H., et al. (2006). Phytoncides (wood essential oils) induce human natural killer cell activity. Immunopharmacology and Immunotoxicology 28, 319-33.

Li, Q., Morimoto, K., Nakadai, A., et al. (2007). Forest bathing enhances human natural killer activity and expression of anti-cancer proteins. International Journal of Immunopathology and Pharmacology 20 (S2), 3-8.

Li, Q., Morimoto, K., Kobayashi, M., et al. (2008a). Visiting a forest, but not a city, increases human natural killer activity and expression of anti-cancer proteins. International Journal of Immunopathology and Pharmacology 21(1), 117-27.

Li, Q., Morimoto, K., Kobayashi, M., et al. (2008b). A forest bathing trip increases human natural killer activity and expression of anticancer proteins in female subjects. Journal of Biological Regulators and Homeostatic Agents (in press).

Mellemgaard, A., Engholm, G., McLaughlin, J.K., \& Olsen, J.H. (1994). Risk factors for renal cell carcinoma in Denmark. I. Role of socioeconomic status, tobacco use, beverages, and family history. Cancer Causes \& Control 5, 105-13.

Menvielle, G., Kunst, A.E., Stirbu, I., et al. (2008). Educational differences in cancer mortality among women and men: a gender pattern that differs across Europe. British Journal of Cancer Feb 19, [Epub ahead of print].

Minami, Y., \& Tateno, H. (2003). Associations between cigarette smoking and the risk of four leading cancers in Miyagi Prefecture, Japan: a multi-site case-control study. Cancer Science 94, 540-7.

Ministry of Health, Labour and Welfare of Japan (2001). http://graphsys.health-net.or.jp/ken-map/01/100f.html.

Ministry of Health, Labour and Welfare of Japan (2003). http://www.mhlw.go.jp/toukei/saikin/hw/c-hoken/03/hyo2.html.

Mizoue, T., Tokui, N., Nishisaka, K., et al. (2000). Prospective study on the relation of cigarette smoking with cancer of the liver and stomach in an endemic region. International Journal of Epidemiology 29, 232-7.

Morita, E., Fukuda, S., Nagano, J., et al. (2007). Psychological effects of forest environments on healthy adults: Shinrin-yoku (forest-air bathing, walking) as a possible method of stress reduction. Public Health 121, 54-63.

Ohtsuka, Y., Yabunaka, N., \& Takayama, S. (1998). Shinrin-yoku (forestair bathing and walking) effectively decreases blood glucose levels in diabetic patients. International Journal of Biometeorology 41 , 125-127.

Park, B.J., Tsunetsugu, Y., Kasetani, T., et al. (2007). Physiological effects of Shinrin-yoku (taking in the atmosphere of the forest)--using salivary cortisol and cerebral activity as indicators. Journal of Physiological Anthropology 26, 123-8.

Toh, C.K., Gao, F., Lim, W.T., et al. (2007). Differences between small-cell lung cancer and non-small-cell lung cancer among tobacco smokers. Lung Cancer 56(2), 161-6.

Tsugane, S. (2004). Dietary factor and cancer risk--evidence from epidemiological studies. Gan to Kagaku Ryoho. Cancer \& Chemotherapy 31, 847-52 (in Japanese).

Umemura, T. (2001). http://www.geocities.jp/umemurat2001/ Works/Okinawa HDI-GDI.pdf (in Japanese)

Yamaguchi, M., Deguchi, M., \& Miyazaki, Y. (2006). The effects of exercise in forest and urban environments on sympathetic nervous activity of normal young adults. The Journal of International Medical Research 34, 152-9. 